\title{
PENERAPAN METODE MIND MAPPING UNTUK MENINGKATKAN PENGUASAAN KONSEP SISWA MATERI KENAMPAKAN PADA PEMBELAJARAN IPS DI SEKOLAH DASAR
}

\author{
Mochamad Yusuf \\ STKIP Bina Insan Mandiri
}

\begin{abstract}
Abstrak
Latar belakang penelitian ini yaitu siswa kelas V SDN Senden Kabupaten Jombang mengalami kesulitan dalam menguasai konsep suatu materi pembelaran IPS. Penyebab permasalahan tersebut adalah guru menggunakan metode yang masih bersifat tradisional yang berpusat pada guru, materi yang disampaikan hanya sebatas pada buku pegangan tanpa ada sumber belajar yang terbaru, dan juga diduga karena pemanfaatan media hanya terbatas pada papan tulis sebagai media mencatat. Oleh karena itu peneliti berpaya memecahkan permasalahan tersebut dengan menerapkan metode mind mapping. Dengan tujuan untuk mengetahui bagaimana peningkatan penguasaan konsep siswa, aktivitas guru, aktivitas siswa, dan respon siswa setelah menerapkan metode mind mapping. Penelitian ini menggunakan metode Penelitian Tindakan Kelas (PTK) yang menggunakan teknik analisis data deskriptif kualitatif dan kuantitatif. Subjek penilitian ini adalah siswa kelas V SDN Senden Kecamatan Peterongan Kabupaten Jombang yang berjumlah 33 siswa. Dilakukan melalui tiga siklus dan setiap siklus terdiri dari perencanaan, pelaksanaan, pengamatan, refleksi. Teknik pengumpulan data menggunakan observasi, tes, dan angket. Instrumen yang digunakan adalah lembar aktivitas guru, lembar aktivitas siswa, lembar tes dan lembar angket. Aktivitas guru mengalami peningkatan selama tiga siklus, pada siklus I yaitu $67,86 \%$, pada siklus II meningkat $85,71 \%$ dan pada siklus III menjadi $89,29 \%$. Peningkatan juga terjadi pada aktivitas siswa dari siklus satu sampai siklus tiga yaitu $69,64 \%, 79,69 \%, 87,5 \%$. Hasil belajar penguasaan konsep siswa mengalami peningkatan pada siklus I hanya mencapai $12,1 \%$ pada siklus II mencapai $66,67 \%$, dan meningkat pada siklus III menjadi $84,85 \%$. Respon yang diberikan siswa dari siklus I yaitu $71,51 \%$, pada siklus II yaitu 79,09\% dan pada siklus III menjadi 83,3\%. Dapat disimpulkan bahwa penerapan metode mind mapping dapat meningkatkan penguasaan konsep siswa materi kenampakan kelas V SDN Sendn Kabupaten Jombang.
\end{abstract}

Kata kunci : pembelajaran IPS, penguasaan konsep, metode mind mapping

\begin{abstract}
Abstarct
The background of this research that the fifth grade students of SDN Senden Jombang have difficulty in mastering the concept of a material social studies. The cause of these problems is the teacher who is still using the traditional teacher-centered, material presented only in the handbook without the latest learning resources, and is also thought to have only limited use of the media as a medium whiteboard notes. Therefore, researchers endeavor to solve these problems by applying the method of mind mapping. By purposing to find out how the enhancement in students' mastery of concepts, teacher activity, student activities, and student responses after applying mind mapping method. This study uses Classroom Action Research (CAR), which uses data analysis techniques of qualitative and quantitative descriptive. Subject of this research is the fifth grade students of SDN Senden Jombang Peterongan totaling 33 students. Having conducted through three cycles and each cycle consisting of planning, implementation, observation, reflection. Data collection techniques being used is observation, tests, and questionnaires. The instrument used is a sheet of teacher activity, student activity sheets, sheet of test and sheet of questionnaire. Teacher activity has increased during the three cycles, the first cycle is $67.86 \%$, the second cycle increased by $85.71 \%$ and the third cycle becomes $89.29 \%$. The enhancement also gets occurred in the student activity of cycle one to cycle three, namely $69.64 \%, 79.69 \%, 87.5 \%$. The results of students' mastery of concepts learned in the first cycle increased only to $12.1 \%$ in the second cycle reaches $66.67 \%$, and increased in the third cycle to $84.85 \%$. The response being provided by students of the first cycle is $71.51 \%$, the second cycle is $79.09 \%$ and the third cycle to $83.3 \%$. It can be concluded that the application of the mind mapping method can improve students' mastery of the concept of class V material appearance SDN Senden Jombang. Keywords: social studies learning, mastery of concepts, appearance, mind mapping method
\end{abstract}




\section{PENDAHULUAN}

Berdasarkan observasi dan wawancara yang dilakukan peneliti pada tanggal 26 September 2013 di SDN Senden Kecamatan Peterongan Kabupaten Jombang khususnya pada siswa kelas V dalam pembelajaran IPS, diketahui pada saat pembelajaran berlangsung terlihat guru sudah berhasil dalam pengondisian kelas. Siswa terlihat memperhatikan guru ketika proses pembelajaran dari awal hingga guru melakukan evaluasi di akhir pembelajaran, meskipun guru hanya menggunakan metode ceramah. Guru selalu bertindak tegas bagi siswa yang ramai atau tidak memperhatikan guru ketika menjelaska. Selain itu guru selalu memberikan pesan moral pada akhir kegiatan pembelajaran, sehingga secara tidak langsung karakter siswa akan terbentuk secara perlahan.

Namun disamping itu peneliti masih menemukan beberapa masalah ketika proses pembelajaran berlangsung, antara lain adalah (1) metode pembelajaran yang digunakan masih bersifat tradisional yang memusatkan kegiatan pada guru, (2) materi yang disampaikan hanya sebatas apa yang ada pada buku pegangan sehingga tanpa mendapatkan materi yang aktual atau terbaru, (3) guru belum memberikan reward pada siswa yang aktif dalam pembelajaran, (4) pemanfaatan media hanya terbatas dalam penggunaan papan tulis sebagai media untuk mencatat. Hal ini terlihat ketika guru menyampaikan materi tidak menggunakan media penunjang yang lain.

Guru selalu menyampaikan materi pembelajaran dengan metode ceramah dan menuliskan cukup banyak catatan yang monoton di papan tulis. Hal tersebut membuat siswa malas untuk belajar. Siswa akan menghabiskan waktu untuk mencari kata penting atau kata kunci dalam catatannya. Padahal tidak semua tulisan siswa rapi dan mudah dibaca. Akhirnya banyak siswa yang cenderung meminjam atau memfotokopi catatan teman yang menurutnya rapi dan mudah dibaca. Hal ini membuat anak menjadi kurang kreatif dan kurang melatih otaknya sendiri. Tidak ada rasa bangga akan catatannya sendiri. Bahkan guru kadang membagikan ringkasan materi. Hal tersebut akan membuat anak menjadi tergantung pada guru dan malas untuk menstimulus kedua belahan otaknya. Siswa tidak dapat membedakan dan mengelompokkan materi yang diberikan oleh guru.

Selain itu, siswa kurang berminat pada pembelajaran yang dilakukan guru. Terbukti ketika guru memberikan pertanyaan, siswa hanya diam tanpa ada respon. Pada saat guru menjelaskan materi di depan kelas, sebagian besar siswa tidak memiliki motivasi untuk mengikuti pelajaran karena bosan dengan metode pembelajaran guru. Mereka sibuk dengan kegiatan masing-masing. Ada siswa yang mengobrol dengan teman sebangkunya, melamun, ada yang mendengarkan tetapi tampak lesu, bahkan ada yang membuka pelajaran lain selain pelajaran IPS. Perilaku siswa tersebut terkesan pembelajaran di sekolah hanya untuk datang, duduk, diam, mendengarkan. Sebagian besar siswa enggan untuk bertanya, mereka hanya diam. Diam yang dimaksudkan peneliti disini adalah diam yaitu bingung yang mau ditanyakan apa karena tidak mengerti materi yang disampaikan dan diam memang mereka benar-benar sudah paham.

Permasalahan yang timbul disebabkan karena pada saat proses pembelajaran berlangsung siswa hanya menerima informasi tanpa adanya keterlibatan dalam pembelajaran. Siswa yang aktif mengemukakan pendapat hanya terbatas pada beberapa siswa saja. Siswa tersebut adalah siswa yang mencapai nilai kriteria ketuntasan minimal (KKM) pada mata pelajaran IPS yang sudah ditentukan sekolah yaitu 70 . Terbukti bahwa pada pembelajaran IPS yang memiliki nilai diatas KKM ada sekitar 39,4\% dari 33 siswa atau sebanyak 13 siswa yang nilainya mencapai KKM. Dengan demikian guru harus mengadakan Program Perbaikan kepada 20 siswa yang belum mencapai KKM.

Permasalahan-permasalahan yang timbul, diduga karena guru masih memiliki pemikiran bahwa sumber belajar hanya terpusat pada dirinya. Selain itu guru juga belum terbiasa menerapkan metode pembelajaran yang inovatif yang dapat mendorong mengeluarkan potensi yang dimiliki oleh siswa. Hal tersebut terbukti ketika peneliti melihat perangkat pembelajaran yang dibuat oleh guru hanya menuliskan model pembelajaran langsung dan metode ceramah. Sedangkan dengan penerapan metode ceramah siswa merasa bosan dan kesulitan memahami materi konsep dari guru.

Penguasaan konsep seharusnya dapat dimiliki oleh setiap siswa. Apabila siswa sudah memiliki penguasaan konsep yang bagus, mereka akan lebih mudah untuk berpikir, mengenal, mengerti, dan memahami terhadap suatu konsep tersebut. Hal ini selaras dengan kurikulum IPS kelas V semester satu pada materi mengenal keragaman kenampakan alam dan buatan serta pembagian waktu di Indonesia. Materi ini dipilih karena dapat memberikan kesempatan dalam meningkatkan kemampuan berpikir dengan menemukan sendiri persoalan yang ada. Siswa akan menemukan dan mengidentifikasi fakta-fakta tentang kenampakan alam maupun buatan yang ada di Indonesia. Setelah itu siswa akan menemukan persamaan ciri-ciri yang muncul dari fakta itu dan akan membedakan atau mengelompokkannya.

Penguasaan konsep pada siswa sangat dipengaruhi oleh kemampuan guru dalam mengelola pembelajaran dalam keberhasilan pencapaian tujuan yang hendak dicapai. Sesuai dengan kurikulum IPS yang bertujuan untuk mengenalkan konsep-konsep yang berkaitan dengan kehidupan masyarakat dan lingkungan, serta memiliki kemampuan dasar untuk berfikir kritis dan rasa ingin tahu untuk memecahkan masalah dalam kehidupan sehari-hari. Sehingga pengenalan atau penguasaan konsep-konsep IPS kepada siswa harus mendalam. Dengan tujuan untuk menjadi bekal dalam menyelesaikan tantangantantangan dalam hidupnya. Penguasaan konsep dalam mata pelajaran IPS dapat dilakukan dengan cara mengerti, memahami, dan menghafalkan konsep- 
konsep tersebut. Maka dari itu guru harus dapat menciptakan proses belajar mengajar yang dapat menumbuh kembangkan potensi anak dalam memahami berbagai konsep pada pembelajaran IPS.

Dalam proses belajar mengajar, penggunaan metode pembelajaran yang tepat sangat menentukan keberhasilan belajar siswa. Penggunaan metode pembelajaran yang tepat, dapat menjadikan siswa mencapai prestasi belajar yang tinggi dan dapat mengembangkan potensi yang tersimpan dalam dirinya, sehingga mereka akan lebih termotivasi untuk belajar IPS dan tidak menganggap IPS sebagai pelajaran yang membosankan karena penuh dengan hafalan-hafalan. Menurut Santrock (2007:7) dalam pembelajaran siswa akan lebih termotivasi jika apa yang dipelajarinya menarik perhatiannya, relevan dengan kebutuhan siswa, menyebabkan mereka puas, dan menambah percaya dirinya. Sebuah tujuan pengajaran yang penting adalah untuk membantu peserta didik memahami konsep utama dalam sebuah subjek daripada hanya mengingat fakta-fakta yang terisolasi.

Salah satu metode yang diduga mampu membantu peserta didik memahami konsep utama dalam sebuah subjek daripada hanya mengingat fakta-fakta adalah mind map. Pemilihan solusi tersebut didasarkan oleh beberapa alasan, antara lain; (1) mind map mempermudah siswa untuk menyusun sebuah konsep dari fakta-fakta yang ditemukan sedemikian rupa otak kita akan bekerja secara alami sehingga siswa akan lebih lama mengingat materi tersebut (2) mind map suatu metode pembelajaran yang sangat baik untuk memahami suatu materi pembelajaran melalui ringkasan catatan dalam bentuk pemetaan pikiran (3) mind map membantu siswa untuk lebih kreatif dan efektif dalam membuat catatan (4) mind map membantu meningkatkan kemampuan penguasaan konsep dengan cara mengidentifikasi, mengklasifikasi, menggolongkan dan membedakan suatu permasalahan melalui diagram warna-warni yang teratur yang dibagi atas tema utama, sub tema, dan urutannya.

Alasan tersebut diperkuat oleh para ahli pendidikan, menurut Buzan (2005:5) mengatakan bahwa mind map merupakan peta rute yang hebat bagi ingatan, memungkinkan kita menyusun fakta dan pikiran sedemikian rupa sehingga cara kerja alami otak dilibat sejak awal. Menurut Buzan (2008:19) bahwa pembelajaran dengan menggunakan metode mind map ini akan membantu anak (1) mudah mengingat sesuatu (2) mengingat fakta angka dan rumus dengan mudah (3) meningkatkan konsentrasi dan motivasi (4) mengingat dan menghafal dengan lebih cepat. Menurut Swadarma (2013:8), mind mapping merupakan cara mencatat yang efektif efisien, kreatif, menarik, mudah dan berdaya guna karena dilakukan dengan cara memetakan pikiran-pikiran kita. Selain itu menurut Swadarma (2013:3), bahwa mind map adalah cara mencatat yang efektif, efisien, kreatif, menarik, mudah, dan berdayaguna karena dilakukan dengan cara "memetakan" pikiran-pikiran kita.

\section{METODE}

Penelitian ini menggunakan metode Penelitian Tindakan Kelas (PTK) karena penelitian dilakukan untuk memecahkan masalah pembelajaran dalam aktivitas pembelajaran di kelas. Penelitian ini juga termasuk penelitian deskriptif, sebab menggambarkan bagaimana suatu teknik pembelajaran diterapkan dan bagaimana hasil yang diinginkan dapat tercapai. Dalam penelitian tindakan kelas ini guru sebagai peneliti, penanggung jawab penuh dalam penelitian. Menurut Trianto (2011:18), tujuan lain dari penelitian tindakan kelas ini adalah untuk memecahkan masalah, memperbaiki kondisi, mengembangkan dan meningkatkan mutu pembelajaran.

Lokasi penelitian ini adalah SDN Senden, yang terletak di desa Senden Kecamatan Peterongan Kabupaten Jombang. Subjek penelitian ini adalah siswa kelas V SDN Senden Kabupaten Jombang yang berjumlah 33 siswa, yang terdiri dari 14 siswa laki-laki dan 19 siswa perempuan.

Teknik pengumpulan data yang digunakan dalam penelitian ini adalah observasi, tes, dan angket. Teknik pengumpulan data digunakan untuk mengumpulkan data aktivitas guru, aktivitas siswa, tes hasil penguasaan konsep, dan respon siswa setelah penerapan metode mind mapping.

Instumen penelitian yang digunakan dalam penelitian ini adalah lembar observasi, lembar tes, dan lembar angket, berdasarkan tujuan pembelajaran yang hendak dicapai. Teknik analisis data merupakan cara yang digunakan untuk menganalisis semua data yang diperoleh dari hasil penelitian. Teknik analisis data yang digunakan pada penelitian ini adalah teknik analisis data kuantitatif dari observasi guru dan siswa, hasil tes penguasaan konsep, serta hasil angket. Sedangkan cara mendeskripsikannya melalui teknis analisis data kualitatif.

Analisis hasil observasi diperoleh dari peneliti berdiskusi dengan guru kelas bersama teman sejawat saat mengamati proses pembelajaran pada setiap siklusnya, yang digunakan untuk mengetahui aktivitas siswa, dan aktivitas guru pada saat kegiatan pembelajaran berlangsung. Analisi ini menggunakan rumus:

$$
\mathrm{P}=\frac{f}{N} \times 100 \%
$$

Keterangan:

$\mathrm{P} \quad=$ Persentase frekuensi kejadian muncul

$f \quad=$ Banyaknya aktivitas guru/siswa yang muncul

$\mathrm{N}=$ Jumlah frekuensi aktivitas keseluruhan

(Indarti, 2008:26)

Secara klasikal sswa telah belajar tuntas jika keberhasilan belajar siswa yang memperoleh nilai $\geq 70$ mencapai $80 \%$. Dihitung dengan menggunakan rumus:

$$
P=\frac{\sum x}{N} \times 100 \%
$$


Keterangan:

$$
\begin{array}{ll}
\mathrm{P} & =\text { presentase } \\
\sum_{\mathrm{N}} \mathrm{x} & =\text { jumlah siswa yang mendapatkan nilai } \geq 70 . \\
& =\text { jumlah siswa seluruhnya. }
\end{array}
$$

(Indarti, 2008:26)

Analisis data tentang respon siswa dianalisis dengan menggunakan rumus:

$$
\mathrm{P}=\frac{f}{N} \times 100 \%
$$

Keterangan:

$$
\begin{array}{ll}
\mathrm{P} & =\text { presentase } \\
\mathrm{f} & =\text { jumlah pemilih } \\
\mathrm{N} & =\text { jumlah siswa keseluruhan }
\end{array}
$$

(Indarti, 2008:26)

Indikator keberhasilan dalam penelitian ini adalah aktivitas guru dan siswa dikatakan berhasil jika mencapai $\geq 80 \%$ dari kesekuruhan aspek yang diamati, siswa dikatakan tuntas dalam menguasaai konsep mendapat nilai $\geq 70$ (KKM),sedangkan secara klasikal dikatakan tercapai bila memperoleh persentase $\geq 80 \%$. Sedangkan respon siswa dikatakan tercapai jika memperoleh persentase $\geq 80 \%$.

\section{HASIL DAN PEMBAHASAN \\ Hasil penelitian}

Dalam poin ini akan dipaparkan hasil penelitian yang telah dilaksanakan di SDN Senden Kabupaten Jombang dengan menerapkan metode mind mapping untuk meningkatkan penguasaan konsep siswa. Penelitian ini dilaksanakan dalam tiga siklus, yang tiap siklusnya terdiri dari dua pertemuan.

Pada tiap siklus selalu melaksanakan tahapantahapan berikut ini: (1) tahap perencanaan, dalam perencanaan meliputi menganalisis kurikulum, menyusun RPP, menentukan media dan sumber belajar, menyusun LKS dan evaluasi, erta menyusun instrumen penilaian; (2) tahap pelaksanaan, pada tahap ini peneliti melaksanakan pembelajaran sesuai RPP dengan menerapkan metode mind mapping; (3) tahap pengamatan, pada tahap pengamatan dilaksanakn bersama pelaksanaan dengan memperhatikan aktivitas siswa dalam pembelajaran; (4) tahap refleksi, refleksi dilaksanakan pada tiap siklus untuk mengetahui keberhasilan dan kendala pada kegiatan pemblajaran dan kemudian dilaksnakan perbaikan pada siklus selanjutnya.
Hasil aktivitas guru, aktivitas siswa, hasil penguasaan konsep, dan respon siswa mulai dari siklus I sampai siklus III akan dijabarkan sebagai berikut:

Tabel 1: Hasil Aktiitas Guru Siklus I-III

\begin{tabular}{|c|c|c|c|}
\hline No. & Siklus & Skor & Prosentase \\
\hline 1. & I & 19 & 67,86 \\
\hline 2. & II & 24 & 85,71 \\
\hline 3. & III & 25 & 89,29 \\
\hline
\end{tabular}

Dari hasil aktivitas guru selama proses pembelajaran disajikan dalam bentuk diagram sebagai berikut:

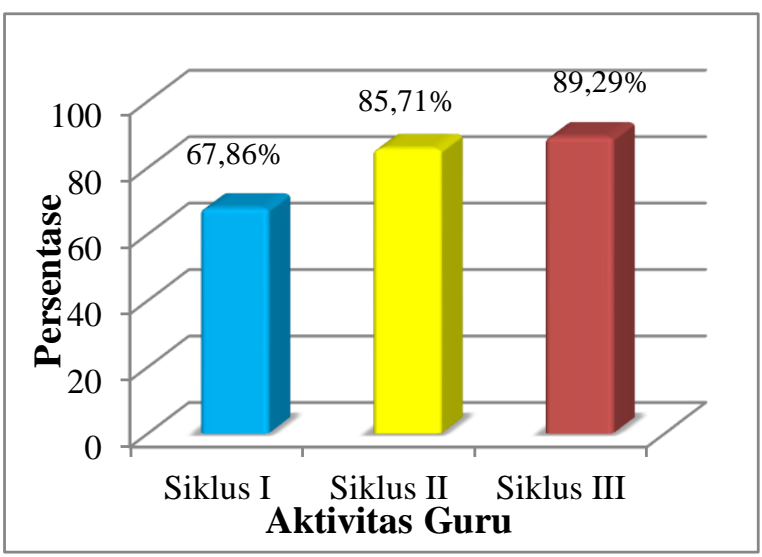

Diagram 1: Hasil Observasi Aktivas Guru Siklus I-III

Berdasarkan tabel 1 dan diagram 1, dapat diketahui bahwa selama proses pembelajaran dengan menerapkan metode mind mapping pada siklus I hingga siklus III sudah terlaksana semua walaupun mengalami kendala-kendala ketika proses pembelajaran berlangsung.

Berdasarakan pengamatan dilakukan oleh kedua observer, selama proses pembelajaran indikator keberhasilan sudah tercapai pada siklus II dengan persentase $85,71 \%$. Pada saat saat siklus I guru sudah baik dalam mempersiapkan siswa dan menyampaikan tujuan pembelajaran. Guru dan siswa bersama-sama mendaftar, menggolongkan, dan memberi nama pada kelompok bentuk-bentuk kenampakan alam. Suara guru yang lantang sehingga bisa menguasai kelas, dan guru memberi pertanyaan sebelum evaluasi dimulai. Kendala yang dihadapi guru belum mengenal karakter siswa, media yang digunakan terlalu kecil sehingga tidak terjangkau hingga bangku belakang, bimbingan kelompok belum dilaksanakan secara maksimal, guru belu mengelolawaktu secara maksimal setiap fase pembelajaran dilaksanakan dengan buru-buru. Siswa masih kesulitan dalam mennggolongkan fakta-fata yang muncul secara mandiri, siswa kesulitan membuat mind map, dalam diskusi kelompok kurang adanya kerjasama dan pembagian kerja yang jelas, dan siswa 
masih belum percaya diri dalam menyampaikan pendapat.

Kemudian pada siklus II guru masih kurang cerat dalam memberikan bimbingan kelompok, guru kurang mendorong siswa untuk menyimpulkan materi secara mandiri. guru lupa meberi pesan moralpada akhir pembelajaran. Pada siklus III pada dasarnya semua hambatan dan kendala dapat teratasi dan proses pembelajaran dengan menerapkan metode mind mapping berjalan ebih meningkat pada setiap siklusnya.

Peningkatan aktivitas siswa dari siklus I hingga siklus III disajikan pada tabel 2 di bawah ini:

Tabel 2: Hasil Aktivitas Siswa Siklus I-III

\begin{tabular}{|c|c|c|c|}
\hline No. & Siklus & Skor & Prosentase \\
\hline 1. & I & 19,5 & 69,64 \\
\hline 2. & II & 25,5 & 79,69 \\
\hline 3. & III & 28 & 87,5 \\
\hline
\end{tabular}

Dari hasil aktivitas siswa selama proses pembelajaran disajikan dalam bentuk diagram sebagai berikut:

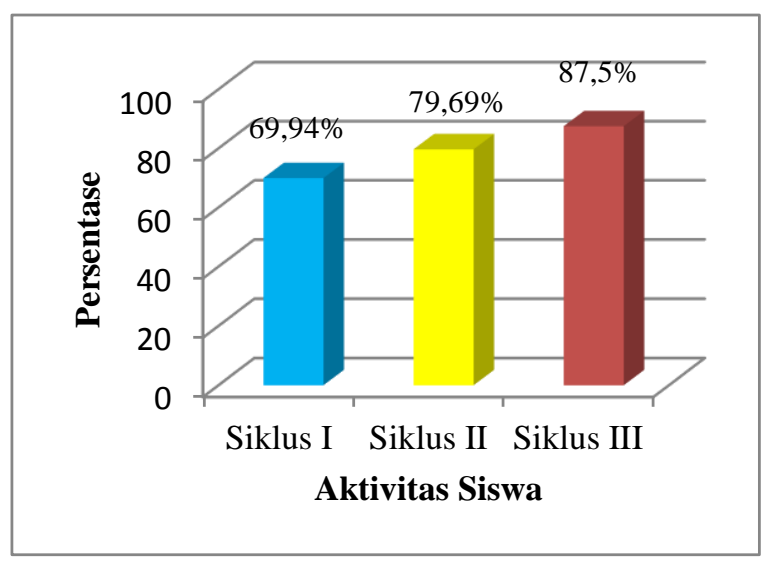

Diagram 2: Hasil Pengamatan Aktivitas Siswa Siklus I, Siklus II, Siklus III

Berdasarkan tabel 2 dan diagaram 2, aktivitas siswa dalam proses pembelajaran dengan menerapkan metode mind mapping yangtelah diamati leh dua observer pada pengamatan aktivitas siswa sudah berhasil terlaksana semua, Pada siklus I mendapat skor $69,94 \%$, siklus II $79,69 \%$, dan siklus III mendapat ketuntasan sebesar 87,5\%. Hal ini menunjukkan peningkatan kemampuan aktivitas siswa dari siklus I hingga sklus III.

Pada siklus I, siswa masih malu-malu dalam bertanya, tidak ada kerjasama dalam berdiskusi, masi dominan pada siswa yang pandai, siswa masih kesulitan menggolongkan fakta-fakta kenampakan alam. Kemudian dilakasanakan perbaikan pada siklus selanjutnya terlihat masil asal-asalan dalam mebuat kesimpulan, dalam presentase yang disampaikan masi kurang jelas dan lengkap. Pada siklus III aktivitas siswa dikatakan berhasil karena mencapai persentase $87,5 \%$.
Persentase data hasil tes pengusaan konsep siswa pada pembelajaran IPS dengan menggunakan metode mind mapping dapat dilihat pada diagram 3 dibawah ini:

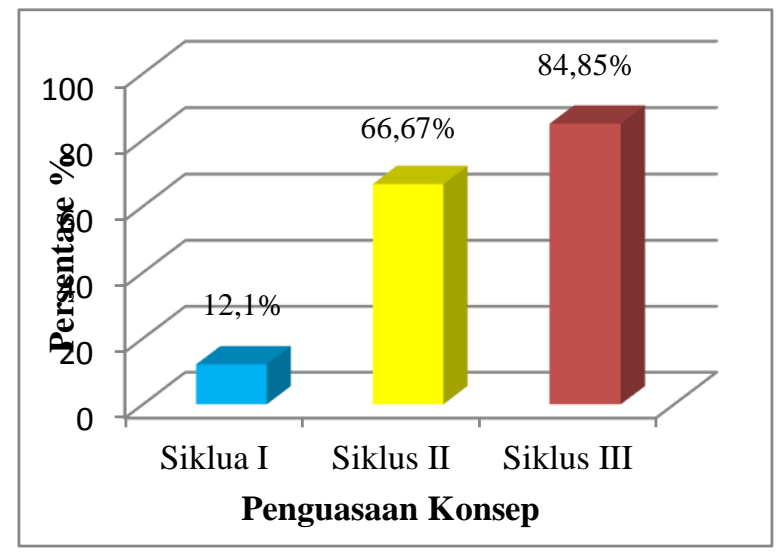

Diagram 3: Hasil Penguasaan Konsep Siklus I, Siklus II, Siklus III

Pada siklus I memperoleh persentase sebesar $12,1 \%$. Banyak siswa yang tidak mencapai KKM. Masih banyak siswa yang kesulitan dalam memahami materi. Siswa kesulitan menemukan kata kunci dalam materi ini. Siswa sulit membandingkan dan mengelompokkan keraaman kenamapakan alam, selain itu siswa belum mengenal mind map. Misalnya siswa masih bingung membandingkan antara gunung dan pegunngan. Selain itu dalam membandingkan kenampakan alam daratan dan perairan masih bingung. Penguasaan konsep hanya dipahami oleh beberapa orang saja. Ketika mengerjakan soal siswa terburu-buru dalam mengerjakan karena waktu yang disediakan guru kurang, sehinggasiswa ada yang tengok kanan tengok kiri agar semua pertanyaan dapat dijawab oleh siswa

Pada siklus II memperoleh persentase $66,67 \%$. Mengalami peningkatan sebesar 54,57\%. Tetapi masih banyak siswa yang kesulitan memahami materi. Tetapi siswa sudah mulai menemukan kata kunci dalam materi ini dengan benar. Siswa kesulitan membandingkan da mengelompokkan keragaman kenampakan alam dan buatan, karena fakta-fakta yang muncul hampir sama.

Pada siklus III ini persentase mencapai $84,85 \%$, dan dapat dikatakan berhasil aatu mencapai indikator meberhasilan yaitu $\geq 80 \%$. Siswa sudah paham dalam mencatat fakta-fakta yang muncul. Siswa juga mampu mengelompokkan berdasarkan jenis kenampakan yang muncul, selain itu siswa mampu memahami kenampakan alam dan buatan yang ada di Indonesia.

Peningkatan respon siswa dari siklus I hingga siklus III disajikan pada tabel 4 di bawah ini:

Tabel 4: Data Hasil Respon Siswa Setiap Siklus 


\begin{tabular}{|c|c|c|c|}
\hline No. & Siklus & Skor & Prosentase \\
\hline 1. & I & 236 & 71,51 \\
\hline 2. & II & 261 & 79,09 \\
\hline 3. & III & 275 & 83,3 \\
\hline
\end{tabular}

Dari hasil peningkatan respon siswa selama proses pembelajaran disajikan dalam bentuk diagram sebagai berikut:

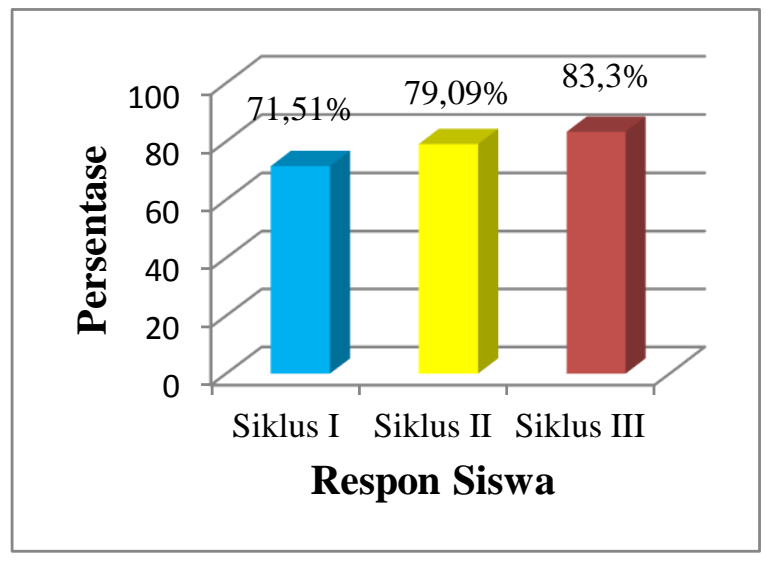

Diagram 4:Persentase Peningkatan Respon Siswa Siklus I - Siklus III

Pada hasil observasi di siklus I dengan persentase $71,51 \%$ dan dinyatakan tinggi, tetapi tidak mencapai keberhasilan. Dengan kata lain, respon siswa kurang terhadap proses pembelajaran. Hal ini menunjukkan bahwa metode ini belum menarik respon siswa terhadap proses pembelajaran. Namun dalam perbaikan selanjutnya dengan mengadakan kunjung karya dan memberikan reward pada aktivitas pembelajaran, terbukti membuat respon siswa semakin meningkat dengan meningkatnya hasil respon siswa pada siklus II dan III. Dan kualitas metode pembelajaran mind mapping ditingkatkan dengan aktivitas-aktivitas yang melibatkan secara langsung bagi siswa. Dikarenakan respon siswa yang baik dalam menanggapi tingkatan fase yang diberikan oleh guru dan terhadap pertanyaanpertanyaan guru. Sehingga mengakibatkan siswa terlihat aktif dalam kegiatan pembelajaran, siswa juga sudah lebih berani mengutarakan pertanyaan dan lebih berani mengemukakan pendapat. Dengan demikian dapat disimpulkan bahwa penerapan metode mind mapping, mendapatkan respon yang baik dari siswa kelas V SDN Senden Jombang.

\section{Pembahasan}

Berdasarkan hasil penelitian dapat diketahui perbandingan hasil observasi aktivitas guru pada siklus I, II, dan III. Pada siklus I persentase aktivitas guru pada saat proses pembelajaran hanya mencapai $67,86 \%$ dinyatakan kurang. Hal ini disebakan karena beberapa faktor yaitu adanya kekurangan-kekurangan pada cara mengajar guru yang meliputi: guru belum mengenal siswa secara keseluruhan, media yang digunakan guru terlalu kecil, bimbingan kelompok belum dilaksanakan secara maksimal, guru belum bisa mengelola waktu secara baik, guru tidak mencantumkan langkahlangkah dalam mengerjakan LKS sehingga siswa merasa kesulitan alam mengerjakan LKS, guru kurang dalam mengajak siswa dalam menyimpulkan materi sehingga hanya sebagian siswa saja yang mengerti dan memahami materi.

Dengan adanya kekurangan-kekurangan aktivitas guru yang terdapat pada siklus I, guru melakukan perbaikan pada siklus II. Dilihat dari aspek menyampaikan tujuan dan mempersiapkan siswa guru memperoleh skor 4 atau presentase keberhasilan 100\% dari siklus I hingga siklus III, berarti guru sudah melakukan kegiatan awal dengan baik. Mulai dari mengucapkan salam, melakukan ice breaking, menyampaikan tujuan pembelajaran dan membuat kontrak belajar dalam mempersiapkan siswa. Hal tersebut sangat dipengaruhi oleh kegiatan guru dalam mempersiapkan rencana pembelajaran, misalnya dengan mempersiapkan RPP yang baik yang dapat meningkatkan penguasaan konsep siswa, menyiapkan LKS dan lembar evaluasi yang sesuai dengan tujuan pembelajaran, serta menyiapkan media yang menarik agar siswa lebih termotivasi dan dapat dijangkau oleh seluruh kelas. Hal tersebut sesuai dengan pendapat Sanjaya (2006:25) kegiatan-kegiatan dalam melaksanakan fungsi perencanaan diantaranya meliputi memperkirakan tuntutan dan dan kebutuhan, menentukantujuan, menulis silabus kegiatan pembelajaran, menentukan topik-topik yang akan dipelajari, mengalokasikan waktu, serta menentukan sumber-sumber yang diperlukan. Melalui fungsi perencanaan ini guru berusaha menjembatani jurang antara murid berada dan kemana harus pergi.

Selain itu pemilihan metode pembelajaran yang tepat, dapat menjadikan siswa mencapai prestasi belajar yang tinggi dan dapat mengembangkan potensi yang tersimpan dalam dirinya, sehingga mereka akan lebih termotivasi untuk belajar. Hal tersebut sesuai dengan pendapat Santrock (2007:7) dalam pembelajaran siswa akan lebih termotivasi jika apa yang dipelajarinya menarik perhatiannya, relevan dengan kebutuhan siswa, menyebabkan mereka puas, dan menambah percaya dirinya.

Kemudian aktivitas guru dalam menyajikan materi pembelajaran memperoleh skor 3 dengan presentase $75 \%$ yang dikategorikan tinggi pada siklus I. Dalam tahapan ini guru belum memanfaatkan media secara maksimal dan media yang digunakan terlalu kecil, sehingga siswa yang duduk di bangku depan saja yang bisa mengamati dan menangkap media tersebut dengan jelas. Kemudian guru melakukan perbaikan pada siklus selanjutnya. Pada siklus II aktivitas guru meningkat 3,5 pada siklus II dengan peningkatan presentase sebesar $12,5 \%$ dan tetap pada siklus III yaitu memperoleh skor 3,5. Dalam perbaikan ini guru menyajikan materi dengan media yang bisa dijangkau oleh seisi kelas, yaitu dengan menggunakan mind mindjet manager. Selain itu guru mengajak siswa mendaftar seluruh kenampakan yang ada, menyebutkan ciri-ciri yang ada pada media yang disajikan oleh guru 
berdasarkan fakta yang ada, kemudian guru dan siswa secara bersama-sama membandingkan kenampakan yang ada berdasarkan persamaan dan perbedaan yang muncul dengan menggunakan mind map dalam bentuk sajian mind mindjet manager. Guru mengajarkan siswa bagaimana cara menemukan ciri-ciri berdasarkan fakta-fakta yang ada, membandingkan, mengelompokkan, dan memberi label sebuah data tersebut dengan mendaftar pada cabang-cabang mind map untuk menemukan alternatif jawaban. Hal tersebut sesuai dengan pendapat Bachmad (2005:51) pemahaman konsep siswa diperoleh dengan cara, yaitu (1) mengatur informasi di dalam satu tema utama dan kaitan pokok-pokoknya (2) mengembangkan bagan konsep yang menggambarkan tema sentral dan konsepkonsepnya yang bertalian, hubungan-hubungan dan saling berkaitan.

Pada aktivitas pembentukan kelompok memperoleh skor 2,5 pada siklus I dengan presentase $62,5 \%$ kategori tinggi, namun sangat minim sekali. Kegiatan pembentukan kelompok guru hanya membentuk kelompok dan membagikan LKS, tanpa menjelaskan tugas-tugas apa saja yang harus dikerjakan dalam kelompok. Guru melakukan perbaikan pada siklus selanjutnya yaitu siklus II dan siklus III, memperoleh skor yang sama yaitu 4 dengan presentase keberhasilan $100 \%$ kategori sangat tinggi. Karena pada siklus II dilakukan perbaikan dengan menjelaskan cara mengerjakan LKS dengan jelas, sehingga siswa tidak kebingungan dalam berdiskusi. Dalam membimbing siswa berdiskusi memperoleh skor 3 presentase $75 \%$ pada siklus I dan siklus II. Bimbingan kelompok belum dilaksanakan secara maksimal, dan belum guru kurang mencermati siswa dalam beriskusi. Guru terus melakukan upaya perbaikan agar memperoleh keberhasilan sesuai indikator yang ditentukan dengan merangsang siswa agar aktif dalam berdiskusi dan menyenangkan. Kemudian mengalami peningkatan sebesar $87,5 \%$ pada siklus III. Pada pembelajaran ini, hal yang paling penting adalah membangun keaktifan siswa melalui diskusi kelompok dan menanamkan lebih dalam ke dalam ingatan siswa mengenai materi yang dipelajari hal ini sesuai penjelasan Trianto (2007:42) bahwa pembelajaran akan lebih memudahkan siswa dalam menemukan dan memahami konsep yang sulit melalui cara berdiskusi dengan temannya. Mengaktifkan siswa dapat dilakukan dalam membimbing kelompok harus menyeluruh dan menyenangkan sehingga akan diperoleh hasil yang maksimal.

Aktivitas lain, yaitu membuat kesimpulan. Pada aspek ini guru melakukan bimbingan dengan memberi contoh yang relevan sehingga siswa tidak bingung dalam membuat kesimpulan. Kesimpulan ditulis di papan tulis, sehingga siswa tidak hanya membayangkan saja namun bisa diulangi dan diperkuat jika ada yang kurang lengkap atau sesuai. Hal tersebut sesuai dengan pendapat Anitah (2007:34), bahwa kegiatan menyimpulkan atau membuat ringkasan materi pelajaran digunakan untuk memantapkan penguasaan siswa terhadap pokok materi, selain itu akan sangat berguna sekali bagi siswa yang tidak memilki sumber buku.

Aktivitas siswa dapat diketahui perbandingan hasil observasi aktivitas guru pada siklus I, II, dan III. Hasil perolehan persentase aktivitas siswa dalam pembelajaran dengan metode mind mapping pada siklus I sebesar 69,94\%, siklus II sebesar 79,89\%, dan siklus III sebesar 87,5\%. Dari setiap siklusnya menunjukkan persentase yang selalu meningkat. Hal ini menunjukkan bahwa aktivitas siswa berkembang dengan baik, seluruh aspek dari semua aktivitas siswa dapat terlaksana walaupun ada beberapa yang kurang.

Pada siklus I hanya mencapai presentase sebesar 69,94\% dengan kategori tinggi, walaupun memperoleh kategori tinggi presentase tersebut belum memenuhi indikator keberhasilan $\geq 80 \%$. Berdasarkan refleksi siklus I kesiapan siswa dalam mengikuti pembelajaran sudah sangat baik, siswa tidak gaduh, namun siswa masih belum terbiasa membuat mind map, dalam diskusi kelompok belum adanya pembagian kerja yang jelas, yang mengerjakan tugas masih dominan pada siswa yang mempunyai kemampuan lebih, siswa belum berani mengajukan pertanyaan kepada guru kalaupun ada masih terlihat ragu-ragu. Kemudian guru melakukan perbaikan pada siklus selanjutnya, upaya tersebut adalah upaya guru untuk meningkatkan aktivitas siswa pada setiap siklusnya.

Pada siklus II presentase aktivitas siswa mencapai $79,69 \%$ dengan kategori tinggi. Namun persentase ini belum mencapai presentase keberhasilan yang ditentukan. Masih terdapat siswa yang malu menyampaikan pendapat, dalam membut kesimpulan masih ada yang asal-asalan dalam membuat kesimpulan, serta pada saat presentasi siswa masih kurang lengkap dalam menjelaskan hasil diskusinya. Peneliti melakukan perbaikan kegiatan pembelajaran pada siklus III. Persentase yang diperoleh pada siklus III yaitu $87,5 \%$ dengan kategori sangat tinggi dan dinyatakan berhasil.

Siswa menyimpulkan materi sesuai data yang relevan dan tidak asal-asalan, pada saat presentasi di depan kelas sudah lengkap dan jelas, siswa sudah banyak yang berani bertanya kepada guru karena guru memberi sebuah reward. Hal ini terbukti dengan pemberian penghargaan siswa semakin antusias dalam mengikuti pembelajaran.

Adanya peningkatan aktivitas siswa dalam proses pelaksanaan pembelajaran dengan menggunakan metode mind mapping, maka dapat dikatakan siswa melaksanakan pembelajaran dengan hasil yang memuaskan sehingga kelas menjadi hidup, siswa menjadi aktif dan antusias untuk mengikuti pembelajaran meningkat. Oleh karena itu metode mind mapping bisa membuat perubahan pada siswa ketika belajar. Dikarenakan gaya belajar siswa berbeda seperti biasanya, siswa bisa lebih antusias dengan menuangkan segala yang ada pada pikirannnya dan siswa memperoleh jawaban dengan hasil pemikirannya sendiri dari pengamatan yang dilakukan. Hal tersebut sejalan dengan teori Buzan (2008:19), bahwa pembelajaran dengan menggunakan metode mind 
mapping ini akan membantu anak: (1) mudah mengingat sesuatu (2) mengingat fakta, angka dan rumus dengan mudah (3) meningkatkan konsentrasi dan motivasi (4) mengingat dan menghafal dengan lebih cepat.

Peningkatan penguasaan konsep siswa yang mengacu pada hasil tes evaluasi pada setiap siklus. Hasil belajar penguasaan konsep pada setiap siklus mengalami peningkatan. Pada awal siklus mendapat presentase yang sangat rendah, yaitu sebesar $12,1 \%$. Hal ini dikarenakan dalam proses pembelajaran guru hanya membuat mind map tanpa menjelaskan kepada siswa bagaimana cara membuat mind map yang benar. Waktu yang digunakan untuk mengerjakan soal evaluasi hanya sedikit sehingga siswa terburu-buru dalam mengerjakan dan tidak konsentrasi. Guru tidak memperhitungkan waktu yang dibutuhkan pada setiap fase pembelajaran. Selain itu media yang digunakan sebagai proses memaknai konsep terlalu kecil, sehingga siswa tidak bisa menjangkau secara keseluruhan. Kemudian dilakukan perbaikan pada siklus selanjutnya. Setelah dilakukan perbaikan yang lebih menekankan penyajian materi dengan metode mind mapping dalam proses pembelajaran, mengulang materi siklus I, mengganti media pembelajaran yang bisa dijangkau oleh seluruh kelas dan pengerjaan soal evaluasi yang sesuai dengan yang diharapkan serta konsentrasi siswa saat mengerjakan presentase keberhasilan meningkat sebesar $66,67 \%$ pada siklus II. Namun peningkatan tersebut belum mencapai indikator keberhasilan yang ditentukan oleh peneliti. Pada siklus III mengalami peningkatan sebesar $84,85 \%$, guru memberi soal yang mengulang materi sebelumnya dan memberikan kuis "Bisa Jadi".

Penelitian sesuai dengan tujuan pembelajaran IPS menurut Wahab dalam Gunawan (2011:21) bahwa tujuan pengajaran IPS tidak semata-mata untuk memberi pengetahuan dan menghafal sejumlah fakta dan informasi akan tetapi lebih dari itu. Para siswa selain diharapkan memiliki pengetahuan mereka juga dapat mengembangkan keterampilannya dalam berbagai segi kehidupan dimulai dari keterampilan akademiknya sampai pada keterampilan sosialnya. Sejalan dengan Slavin (dalam Rosalia,2013:1) kecakapan siswa dalam memahami materi sangat diperlukan karena hal itu berpengaruh pada hasil belajar siswa dan penguasaan konsep yang ada di diri siswa. Hal yang demikian jauh lebih bermakna dalam memberikan penguasaan konsep bagi siswa bila dibandingkan dengan penelitian yang dilakukan Rosalia yang meningkatkan penguasaan konsep dengan model NHT. Didapatkan hasil pada siklus I sebesar $69,23 \%$ dan siklus II sebesar 78,29. Hasil tersebut mengalami peningkatan dan tuntas secara keberhailan yang ditetapkan oleh Rosalia (2013). Dalam pelaksanaannya, mengalami banyak kendala untuk menigkatkan penguasaan konsep siswa. Dari meningkatnya hasil dari siklus I ke siklus II, Rosalia (2013) mengambil tindakan memberikan soal yang sama, kemudian memberikan penjelasan materi kepada siswa.

Perbaikan tersebut berbeda dengan perbaikan yang dilakukan oleh peneliti, yaitu dengan memberikan motivasi minat belajar dengan memberikan reward pada siswa, memberi bentuk pembelajaran yang lain tiap siklusnya seperti kunjung karya pada siklus II dan melakukan kuis "Bisa Jadi" pada siklus III. Guru mengajak siswa mendaftar seluruh kenampakan yang ada, menyebutkan ciri-ciri yang ada pada media yang disajikan oleh guru berdasarkan fakta yang ada, kemudian guru dan siswa secara bersama-sama membandingkan kenampakan yang berdasarkan persamaan dan perbedaan yang muncul dengan menggunakan mind map dalam bentuk sajian mind mindjet manager. Guru mengajarkan siswa bagaimana cara menemukan ciri-ciri berdasarkan fakta-fakta yang ada, membandingkan, mengelompokkan, dan memberi label sebuah data tersebut dengan menggunakan cabang-cabang mind map untuk menemukan alternatif jawaban. Secara tidak secara langsung guru memberikan penjelasan materi pada siswa, namun siswa yang menemukan dan menganlisis konsepkonsep materi kenampakan itu sendiri dengan menggunakan cabang-cabang pada mind map. Tentunya dengan tahapan metode mind mapping. Hal inilah yang membedakan penelitian yang dilakukan Rosalia (2013) yang memberikan penjelasan materi di awal pelajaran terhadap siswa.

Ini terbukti dengan penerapan metode mind mapping dapat meningkatkan penguasaan konsep siswa, apalagi dengan inovatif perlakuan yang diberikan pada saat proses pembelajaran. Selain perlakuan tersebut, kualitas dari tahapan metode sangat berpengaruh dengan memaknai pembentukan konsep untuk siswa. Hal tersebut sesuai dengan pendapat Bachman (2005:51) pemahaman konsep siswa diperoleh dengan cara, yaitu (1) mengatur informasi di dalam satu tema utama dan kaitan pokok-pokoknya (2) mengembangkan bagan konsep yang menggambarkan tema sentral dan konsep-konsepnya yang bertalian, hubungan-hubungan dan saling berkaitan. Hal tersebut dapat diaplikasikan dengan menggunakan metode mind mapping. Sejalan dengan pendapat DePorter (1992:173) manfaat peta pikiran adalah fleksibel, memusatkan perhatian, meningkatkan pemahaman, dan menyenangkan. Peningkatan pemahaman, ketika membaca suatu tulisan atau laporan teknik, peta pikiran akan meningkatkan pemahaman dan memberikan tinjauan ulang yang sangat brarti nantinya.

Dapat disimpulkan bahwa metode mind mapping berdampak positif dalam proses pembelajaran dan hal tersebut berpengaruh pada hasil belajar penguasaan konsep siswa. Selain itu dalam metode mind mapping berpengaruh pada keterampilan sosialyang dimiliki siswa, ha;i ini terlihat saat pada fase pembentukan kelompok dan berdiskusi. Setiap siswa belajar bagaimana menghargai pendapat orang lain, bekerjasama dalam kelompok, saling tolong menolong saat teman sekelompok mengalami kesulitan, dan siswa diharuskan tidak untuk bergantung pada orang lain. 
Peningkatan respon siswa dari siklus I hingga siklus III dipaparkan sebagai berikut. Pada hasil observasi di siklus I dengan persentase $71,51 \%$ dan dinyatakan tinggi, tetapi tidak mencapai keberhasilan. Dengan kata lain, respon siswa kurang terhadap proses pembelajaran. Hal ini menunjukkan bahwa metode ini belum menarik respon siswa terhadap proses pembelajaran. Namun dalam perbaikan selanjutnya dengan mengadakan kunjung karya dan memberikan reward pada aktivitas pembelajaran, terbukti membuat respon siswa semakin meningkat dengan meningkatnya hasil respon siswa pada siklus II dan III. Dan kualitas metode pembelajaran mind mapping ditingkatkan dengan aktivitas-aktivitas yang melibatkan secara langsung bagi siswa. Dikarenakan respon siswa yang baik dalam menanggapi tingkatan fase yang diberikan oleh guru dan terhadap pertanyaan-pertanyaan guru. Sehingga mengakibatkan siswa terlihat aktif dalam kegiatan pembelajaran, siswa juga sudah lebih berani mengutarakan pertanyaan dan lebih berani mengemukakan pendapat. Dengan demikian dapat disimpulkan bahwa penerapan metode mind mapping, mendapatkan respon yang baik dari siswa kelas V SDN Senden Jombang.

\section{PENUTUP}

\section{Simpulan}

Aktivitas guru dalam pembelajaran IPS melalui metode mind mapping mengalami peningkatan. Aktivitas guru selama siklus I hingga siklus III sudah mengalami peningkatan. Guru merencanakan kegiatan pembelajaran dan sumber belajar dengan baik, mengelola kelas sehingga suasana kelas kondusif, membimbing siswa berdiskusi, presentasi di depan kelas, mendaftar fakta-fakta yang ada, membantu siswa menganalisis persamaan dan perbedaan yang muncul, menggologkan, hingga menyimpulkan data.

Aktivitas siswa dalam pembelajaran IPS melalui metode mind mapping mengalami peningkatan. Aktivitas siswa selama siklus I hingga siklus III sudah mengalami peningkatan. Siswa lebih berpartisipasi dalam proses pembelajaran, menunjukkan sikap yang baik, lebih berani menyatakan bendapat dan bertanya, serta lebih antusias dalam mengikuti proses pembelajaran.

Peningkatan penguasaan konsep siswa materi kenampakan melalui penerapan metode mind mapping dalam pembelajaran IPS sangat baik. Hal ini ditunjukkan pada hasil belajar terhadap pembelajaran IPS di setiap siklus mengalami peningkatan.

Respon siswa dengan penerapan metode mind mapping pada pembelajaran IPS dapat dikatakan sangat tinggi. Hal ini ditunjukkan pada data angket siswa terhadap pembelajaran IPS di setiap siklus mengalami peningkatan.

\section{Saran}

Guru hendaknya menerapkan metode mind mapping pada materi yang memunculkan banyak alternatif jawaban, dengan memancing siswa beberapa pertanyaan. Karena dalam mind mapping merangsang siswa untuk menjawab pertanyaan lebih dari satu jawaban, lebih efektif dalam menyebutkan menggolongkan, mengidentifikasi, dan menyimpulkan dengan menggunakan cabang-cabang yang ada pada unsur mind map yang berhubungan dengan konsep.

Guru hendaknya memfasilitasi siswa dalam pembelajaran IPS dengan menggunakan metode mind mapping, agar siswa menjadi lebih aktif dalam pembelajaran seperti memberikan kunjung karya pada proses pembelajaran, mengajak siswa keluar kelas untuk melakukan pengamatan lingkungan sekitar dan melatih kerjasama dalam kelompok. Pada akhirnya aktivitas siswa pada saat proses pembelajaran berlangsung menjadi hidup dan berkembang.

Soal evaluasi yang diberikan pada siswa, hendaknya lebih mengarah yang berkenaan dengan penguasaan konsep dan disesuaikan dengan materi yang ada. Dalam pembuatan soal evaluasi harus lebih menggunakan bahasa yang mudah dipahami oleh siswa.

Supaya respon siswa terhadap pembelajaran konsep lebih meningkat, guru hendaknya mengembangkan pembelajaran IPS dengan baik dan memilih metode pembelajaran yang tepat. Seperti memancing siswa menggunakan reward, agar siswa termotivasi mengikuti pembelajaran. Karena dengan metode mind mapping siswa merasa senang bisa mengeksplorasi pengetahuan yang dimiliki sesuai materi, bisa berkonsentrasi penuh atau memusatkan pikiran dan antusias meningkat selama pembelajaran berlangsung sehingga mendapatkan hasil belajar yang optimal.

\section{DAFTAR PUSTAKA}

Anitah, Sri W. 2011. Strategi Pembelajaran di SD. Jakarta: Universitas Terbuka.

Bachman, Edmund. 2005. Metode Belajar Berpikir Kritis Dan Inovatif. Jakarta: Prestasi Pusaka.

Buzan, Tony. 2008. Buku Pintar Mind Map Untuk Anak. Jakarta: PT Gramedia Pustaka Utama. . 2005. Buku Pintar Mind Map. Jakarta: PT Gramedia Pustaka Utama.

DePorter, Bobbi, \& Mike Hernacki. 2008. Quantum Learning. Bandung: Kaifa.

Gunawan, Rudi. 2011. Pendidikan IPS Filosofi, Konsep, dan Aplikasi. Bandung: Alfabeta.

Indarti, Titik. 2008. Penelitian Tindakan Kelas (PTK) dan Penelusuran Ilmiah. Surabaya: FBS UNESA.

Rosalia, Lia Angela. 2013. Peningkatan Penguasaan Konsep Kenampakan Alam dalam Pelajaran 
IPS Melalui Model Pembelajaran Kooperatif Tipe NHT.

http://jurnal.fkip.uns.ac.id/index.php/pgsdsolo/ article/view/430 (Vol 2, No. 4 tahun 2013) (diunduh hari Kamis tanggal 3 Oktober 2013 pukul 00.39)

Sanjaya, Wina. 2006. Startegi Pembelajaran Berorientasi Standar Proses Pendidikan. Jakarta: Kencana.

Santrock, John W. 2007. Psikologi Pendidikan. Jakarta: Kencana Prenada Media Group.

Swadarma, Doni. 2013. Penerapan Mind Mapping Untuk Kurikulum Pembelajaran. Jakarta: PT Elex Media Komputindo.

Trianto. 2011. Panduan Lengkap Penelitian Tindakan Kelas. Jakarta: Prestasi Pusaka. 